\title{
Resistance of different wood-based materials against mould fungi: a comparison of methods
}

\author{
Arne A.P. Imken ${ }^{1} \cdot$ Christian Brischke $^{1} \cdot$ Sebastian Kögel ${ }^{1} \cdot$ Kim C. Krause $^{1} \cdot$ Carsten Mai $^{1}$
}

Received: 13 November 2019 / Published online: 22 June 2020

(c) The Author(s) 2020

\begin{abstract}
Wood-based materials are generally prone to colonization by mould fungi and other discoloring microorganisms, but their resistance to fungal discoloration varies. Different standardized test methods for determining the susceptibility to mould fungi have been used to evaluate various wood-based materials, but the obtained results suggest that mould resistance depends on the method applied. Therefore, this study aimed at a comparative evaluation of two commonly used methods for determining the mould resistance of wood-based materials, i.e. the chamber method according to BS 3900—Part G6 and the malt agar plate method according to ISO 16869. Solid wood, wood fiber insulation boards and wood polymer composites were inoculated, incubated for different time intervals, and assessed with regard to superficial mould growth. Mould growth ratings obtained with the two methods did not correlate well, neither within one type of material nor across different materials, which can be attributed to higher moisture contents and additional nutrients available for the specimens in the agar plate test compared to those in the chamber test. It was concluded, that the experimental set up could have an overriding effect on the results of mould resistance tests.
\end{abstract}

\section{Introduction}

Numerous fungi have potential to negatively affect the performance of wood-based materials through cell wall degradation or superficial deterioration of its optical appearance. Besides various decay fungi, which can cause brown, white, or soft rot, different blue stain and mould fungi can lead to discoloration of wood. Mould fungi mostly belong to the group of fungi imperfecti and are therefore micro-fungi. Even though mould fungi do not influence the strength properties of wood-based materials (Schmidt 1994), they affect their appearance and can cause allergic responses (Sutter 2002; Robbins and Morrell 2002).

Growth of mould fungi requires a wood moisture content between 30 and $150 \%$, temperature between 0 and $40{ }^{\circ} \mathrm{C}$ and easily accessible nutrients (Sutter 2002). Typically, mould fungi are forming surface mycelium, which can release spores through conidia.

Arne A.P. Imken

arne.imken@uni-goettingen.de

1 Wood Biology and Wood Products, Faculty of Forestry and Forest Ecology, University of Goettingen, Büsgenweg 4, 37077 Göttingen, Germany
Mould fungi can infect nearly all materials, i.a. wood polymer composites or wood fiber insulation boards. Wood polymer composites (WPC) are composite materials made from wood, polymers such as polyethylene (PE), polypropylene (PP) and polyvinyl chloride (PVC), and different additives. The latter may be coupling agents, lubricants, fungicides or dyes. Usually, the wood percentage in WPC is $50-70 \%$ (Karus et al. 2006). Production of WPC proceeds in a continuous extrusion process or in a discontinuous injection moulding process. Typical applications of WPC are deckings, claddings, and fence elements.

Wood fiber insulation boards (WFIB) are usually made of softwood fibers obtained through thermomechanical pulping (TMP): wood chips are thermally treated with steam at high pressure and afterwards defibrillated in a refiner (Krug 2010). The boards are produced in a wet or in a dry process, where the latter is more common today. Usually polymeric methylendiphenylisocyanate (PMDI) serves as binder. Optionally, hydrophobic additives or fungicides can be added (Holzmann et al. 2012).

Different standardized test methods are available for evaluating the susceptibility of wood-based materials to mould fungi (e.g. ISO 16000-21, 2014; ASTM D 3273-00, 2000; EN 15457, 2014; EN 60068-2-10, 2006; ISO 846, 2018; EN 15101-1, 2013 and EN 15534-1, 2018). Only EN 15534-1 
is related to WPC and only EN 15101-1 is related to WFIB, all others were developed for testing of building materials, plastics and coatings. Nevertheless, the purpose of this study was to compare the two mainly used standards for evaluating mould growth on wood in Europe, the British standard BS 3900-Part G6 (1989) and the ISO standard 16869 (2008), and to evaluate whether the ratings obtained correlate with each other.

BS 3900-Part G6 (1989) is usually applied to test the performance of paints on various substrates such as wood, metal, and plaster. To test panels of different wood species, Scots pine sapwood (Pinus sylvestris) is used as a reference. Painted flat panels are inoculated with a spore suspension (Aspergillus versicolor, Aureobasidium pullulans, Cladosporium cladosporioides, Penicillium purpurogenum, Phoma violacea, Rhodotorula rubra, Sporobolomyces roseus, Stachybotrys atra and Ulocladium atrum). The test takes place in an incubation chamber with optimum temperature and humidity for fungal growth. Evaluation of fungal growth proceeds via optical assessment after 28 days and rating in one of five classes. The test is extendable for up to twelve weeks. The specimens are levitating and have no direct contact with water.

ISO 16869 (2008) serves to evaluate the effectiveness of fungistatic compounds in plastic formulations. Discshaped specimens are embedded in nutrient-salt agar in an agar plate and a fungal spore suspension (Aspergillus niger, Chaetomium globosum, Paecilomyces variotii, Penicillium funiculosum and Trichoderma longibrachiatum) is added. As a reference, malt-extract agar is embedded instead of a specimen in the agar plate. The plates are inoculated for 21 days. The specimens are laying on agar and have direct contact to water.

Previous studies showed that mould fungi were the first colonizers on WPC material after three months of outdoor exposure (Plaschkies and Scheiding 2014). Ibach et al. (2013) compared decay of WPC from outdoor exposure and in the laboratory. They found mould and algae as the first colonizers. Ibach (2010) also mentioned that the effects of mould fungi are difficult to stop without periodic washing with dilute bleach solution. Lie et al. (2019) compared laboratory screening tests and outdoor performance of exterior wooden claddings. They used agar plate tests and water uptake tests as laboratory methods. The authors investigated various inoculation methods and incubation temperatures. They did not find any significant correlation between the agar test and the outdoor test, but they established significant correlations between the water uptake test and the outdoor test, namely between the water uptake of the specimens and the mould rating of the same specimens after 126 days of outdoor exposure. Scheiding (2007) pointed out that there is a lack of an explicit standard for testing the resistance to mould fungi for wood-based materials including WFIB.
Kumar et al. (2016) used octadecyltrichlorosilane for hydrophobic surface treatment of wood fibers to reduce the susceptibility for microorganisms. According to EN ISO 846 (2018), it improved the effectiveness towards mould significantly. Hundhausen et al. (2013) identified the accuracy of the visual assessment as strongly dependent on the evaluator, the type of rating scale and the standard used. They developed a procedure that enabled objective determination of mould growth by using the public domain software ImageJ.

The aim of this study was to compare two standard methods most commonly used for testing the mould resistance of wood-based materials in Europe and to figure out whether the corresponding results correlate. Therefore, two very different types of wood-based materials were compared, i.e. wood polymer composites (WPC) and wood fiber insulation boards (WFIB). Solid wood and pure polymers were tested as references. Mould resistance tests were performed according to BS 3900-Part G6 (1989) and ISO 16869 (2008). It was hypothesized that hardwood containing materials are more susceptible to mould growth compared to softwood containing products due to a higher hemicellulose content and that the mould resistance of WPC decreases with rising wood content.

\section{Materials and methods}

\subsection{Materials}

Different types of materials, wood (Scots pine sapwood, beech, black locust purchased from Lower Saxony State Forests) and polymer references (polypropylene from Sabic (Saudi Basic Industries Corporation, Riyadh, Saudi Arabia) and polyethylene from Braskem (Sao Paulo, Brazil)), wood-polymer-composites (WPC) and wood fiber insulation boards (WFIB) were used in this study. For both tests, specimens of the references and WPC had a thickness of $4 \mathrm{~mm}$ while the specimens of the WFIB had a thickness of $36 \mathrm{~mm}$. For the tests according to BS 3900G6 (1989), the specimens were $30 \mathrm{~mm} \times 20 \mathrm{~mm}$ with a 2 $\mathrm{mm}$ bore-hole drilled $4 \mathrm{~mm}$ from the mid-point of the 20 $\mathrm{mm}$ side of the references and the WPC specimens. The WFIB specimens did not exhibit a hole. Specimens used for tests according to ISO 16869 (2008) were $20 \mathrm{~mm} \times 20$ $\mathrm{mm}$. All test specimens were conditioned at $20 \pm 2{ }^{\circ} \mathrm{C}$ and $65 \pm 10 \%$ relative humidity $(\mathrm{RH})$ until constant mass. The number of replicates for each test and material was five references, five WPC specimens, and six WFIB specimens. For WFIB specimens, the higher number of replicates was chosen because two boards per variation were produced and three specimens per board were analyzed. 


\subsubsection{Production of wood-polymer composites (WPC)}

WPC produced in an extrusion (EX), injection molding (IM) and compression molding (CM) process had different shapes; some were solid boards, and some were hollowchamber profiles. They were partly produced industrially by different industrial partners, partly in laboratory processes conducted by "Süddeutsches Kunststoff-Zentrum (SKZ)" in Würzburg, Germany (WPC 1-3) and partly in cooperation with the Institute of Polymer Materials and Polymer Technology (PuK) at the TU Clausthal, Germany (WPC 4-9). Specimens of industrially produced WPC decking were cut from the inner layer of the material and had accordingly a non-sealed surface with exposed wood particles. Specimens of WPC 1 and 2 were cut from the lateral surface area of the extruded rectangular hollow-chamber profiles. The resulting specimens had a smooth top side and a rough bottom side.
The compression molded WPC 3 as well as the injection molded WPC formulations 4-9 had smooth surfaces on both sides of the specimens. Details about the wood species, polymer matrix, and pre-weathering are summarized in Table 1.

\subsubsection{Production of wood fiber insulation boards (WFIB)}

Specimens were cut from sanded boards produced in a dry process in the Section of Molecular Wood Biotechnology and Technical Mycology, Faculty of Forest Science and Forest Ecology, University of Goettingen. The tested WFIB were made either solely from Norway spruce fibers (Picea abies) or from mixtures of Norway spruce with various hardwood fiber blends in proportions of 20,50 and $80 \%$. The hardwood fiber blends contained equal proportions of European ash (Fraxinus excelsior), European beech (Fagus sylvatica) and silver birch (Betula pendula). Two types of

Table 1 Wood-polymer composites (WPC), wood and polymer references, wood species, wood percentages, manufacturing method and density

\begin{tabular}{|c|c|c|c|c|c|}
\hline Material & Polymer matrix & Wood species & $\begin{array}{l}\text { Wood percent- } \\
\text { age }(\%)\end{array}$ & $\begin{array}{l}\text { Manufacturing } \\
\text { method }\end{array}$ & Density $\left(\mathrm{kg} / \mathrm{m}^{3}\right)$ \\
\hline Scots pine sapwood & - & Pinus sylvestris & 100 & & 513 \\
\hline Beech & - & Fagus sylvatica & 100 & & 667 \\
\hline Black locust & - & Robinia pseudoacacia & 100 & & 689 \\
\hline Polypropylene & - & - & 0 & $\mathrm{IM}^{1}$ & 883 \\
\hline Polyethylene & - & - & 0 & $\mathrm{IM}$ & 951 \\
\hline WPC 1 & Polypropylene & Softwood ${ }^{5}$ & 60 & $\mathrm{EX}^{2}$ & 937 \\
\hline WPC 2 & Polypropylene & Softwood & 70 & EX & 1112 \\
\hline WPC 3 (plus biocide ${ }^{4}$ ) & Polypropylene & Softwood & 60 & $\mathrm{CM}^{3}$ & 1076 \\
\hline WPC-Industrial 1 & Polypropylene & n.a. & 60 & & 1120 \\
\hline WPC-Industrial 2 & Polyvinyl chloride & n.a. & 50 & & 1314 \\
\hline WPC_-Industrial 3 & Polyethylene & n.a. & 75 & & 1235 \\
\hline WPC_-Industrial 4 & Polypropylene & Pulp & 50 & & 1143 \\
\hline WPC-Industrial 5 & Polyvinyl chloride & n.a. & 50 & EX & 1337 \\
\hline WPC-4-poplar & Polypropylene & Populus spp. & 60 & $\mathrm{IM}$ & 1096 \\
\hline WPC-5-willow & Polypropylene & Salix spp. & 60 & $\mathrm{IM}$ & 1084 \\
\hline WPC-6-spruce & Polypropylene & Picea abies & 60 & $\mathrm{IM}$ & 1074 \\
\hline WPC 7-spruce industrial & Polypropylene & Softwood & 60 & $\mathrm{IM}$ & 1139 \\
\hline WPC 8-young beech & Polypropylene & Fagus sylvatica & 60 & $\mathrm{IM}$ & 1079 \\
\hline WPC 9-old beech & Polypropylene & Fagus sylvatica & 60 & $\mathrm{IM}$ & 1091 \\
\hline $\begin{array}{l}\text { WPC-Industrial } 1 \\
\left(4 \text { years o.e. }{ }^{6}\right)\end{array}$ & Polypropylene & n.a. & 60 & & 1137 \\
\hline $\begin{array}{l}\text { WPC-Industrial } 2 \\
\text { (6 yearso.e.) }\end{array}$ & Polyvinyl chloride & n.a. & 50 & & 1310 \\
\hline $\begin{array}{l}\text { WPC-Industrial } 3 \\
\text { (1 yearo.e.) }\end{array}$ & Polyethylene & n.a. & 75 & EX & 1130 \\
\hline
\end{tabular}

${ }^{1}$ Injection moulding

${ }^{2}$ Extrusion

${ }^{3}$ Compression moulding

${ }^{4}$ Biocide $=$ preservative against mould growth (industrial product)

${ }^{5}$ Softwood source: raw cellulose (industrial product)

${ }^{6}$ Outdoor exposure 
Table 2 Wood fiber insulation boards (WFIB), respective binders/ additives and density

\begin{tabular}{lll}
\hline Material & Binders/additives & Density $\left(\mathrm{kg} / \mathrm{m}^{3}\right)$ \\
\hline 20SW $1 / 80 \mathrm{HW}^{2}$ & PMDI $^{3}(5 \%)$ & 116,5 \\
50SW/50HW & PMDI (5\%) & 114,4 \\
80SW /20HW & PMDI (5\%) & 108,9 \\
100 Spruce & PMDI (5\%) & 106,5 \\
20SW/80HW & PMDI (5\%) \& APP 4 (10\%) & 112,2 \\
50SW/50HW & PMDI (5\%) \& APP (10\%) & 113,5 \\
80SW/20HW & PMDI (5\%) \& APP (10\%) & 106,4 \\
100 Spruce & PMDI (5\%) \& APP (10\%) & 104,2 \\
20SW/80HW & Bico (7\%) & 110,2 \\
50SW/50HW & Bico (7\%) & 103,8 \\
80SW/20HW & Bico (7\%) & 98,7 \\
100 Spruce & Bico (7\%) & 99,3 \\
20SW/80HW & PMDI (5\%) \& paraffin (1\%) & 111 \\
50SW/50HW & PMDI (5\%) \& paraffin (1\%) & 107,7 \\
80SW/20HW & PMDI (5\%) \& paraffin (1\%) & 107,2 \\
100 Spruce & PMDI (5\%) \& paraffin (1\%) & 111,7 \\
\hline
\end{tabular}

${ }^{1}$ Softwood

${ }^{2}$ Hardwood

${ }^{3}$ Polymeric methylendiphenylisocyanate

${ }^{4}$ Ammonium polyphosphate

binders-low temperature curing poly-methylendiphenylisocyanate (PMDI) resin (I-Bond WFI 4370) and bicomponent fibers (Bico-Fibers) - were used to produce either stiff or flexible boards. Further additives used were paraffin wax as hydrophobic agent and ammonium polyphosphate (APP) as flame retardant (Table 2). The percentages of the additives always refer to the dry mass of the fibers.

\subsection{Mould fungi}

To prepare the spore suspension, $5 \mathrm{ml}$ of a wetting agent ( $0.05 \%$ polysorbate dissolution) was added to the cultured (for six to eight weeks) mould fungi, cultivated in agar plates on potato dextrose agar or on malt agar. The different media were selected to provide ideal growth conditions for each fungal species. Afterwards, the spores were harvested with a sterile inoculating loop and all mixed in a beaker. The number of cultures per fungi differed between one and five. To make the standards comparable, a unique spore suspension was used. Differing from the suggested fungi in the standards for all mould resistance tests, the following fungi were used: Aspergillus niger (ATCC 6275), Aspergillus versicolor (IMI 45554), Chaetomium globosum (ATCC 6205), Cladosporium cladosporioides (IMI 178517), Penicillium purpurogenum (IMI178519), Paecilomyces variotii (CBS 628.66), Rhodotorula rubra (main name of strain ID: Rhodotorula mucilaginosa) (NCYC 1659), Stachybotrys atra (IMI 082021), Sydowia polyspora (IMI 269217), Trichurus spiralis (MG 31) and Ulocladium atrum (IMI 79805).

\subsubsection{Assessment of mould resistance according to BS 3900—Part G6 (1989)}

An incubation chamber $\left(40 \times 25 \times 25 \mathrm{~cm}^{3}\right)$ was used for the mould resistance tests according to BS 3900-G6 (1989). The conditioned specimens were inoculated via an atomizer with $1 \mathrm{ml}$ of mixed spore suspension. Potential contamination after inoculation was accepted, because the contamination would be with mould fungi again. After inoculation, the specimens were placed in the incubation chamber over a water reservoir with a heating coil. Hooks were plugged through the WPC holes or directly through the WFIB and
Fig. 1 Incubation chamber used for mould resistance tests according to BS 3900 (1989)








Fig. 2 Screw jar with an inoculated WFIB-specimen in a mould resistance test according to ISO 16869 (2008)

were hung up on metal ledges (Fig. 1). The temperature of the room, where the incubation chamber was stored, was 23 ${ }^{\circ} \mathrm{C} \pm 2{ }^{\circ} \mathrm{C}$. Heating of the water reservoir in the incubation chamber proceeded every $10 \mathrm{~h}$ for $2 \mathrm{~h}$ throughout the incubation. Temperature and relative humidity were checked every day. Specimens were assessed visually-in the beginning every 2 days, subsequently at larger intervals up to 12 days. Images were taken using a digital microscope VHX 5000 (Keyence, Osaka, Japan) at $50 \mathrm{x}$ magnification. The incubation period was 60 days.

\subsubsection{Assessment of mould resistance according to ISO 16869 (2008)}

The WPC specimens were placed in the center of screw jars (diameter: $115 \mathrm{~mm}$, height: $70 \mathrm{~mm}$ ), which were previously filled with $20 \mathrm{ml}$ of nutrient-salt-agar $\left(2.62 \mathrm{~g} \mathrm{KH}_{2} \mathrm{PO}_{4}, 0.2\right.$ $\mathrm{g} \mathrm{Na}_{2} \mathrm{HPO}_{4} \cdot 2 \mathrm{H}_{2} \mathrm{O}, 0.7 \mathrm{~g} \mathrm{MgSO}_{4} \cdot 7 \mathrm{H}_{2} \mathrm{O}, 1.0 \mathrm{~g} \mathrm{NH}_{4} \mathrm{NO}_{3}$, $15.0 \mathrm{~g}$ agar-agar, and $10 \mathrm{ml}$ stock solution of micro-nutrients per $1000 \mathrm{ml}$ aqueous solution). The solution of micronutrients contained $0.5 \mathrm{~g} \mathrm{NaCl}, 0.2 \mathrm{~g} \mathrm{FeSO}_{4} \cdot 7 \mathrm{H}_{2} \mathrm{O}, 0.2 \mathrm{~g}$ $\mathrm{ZnSO}_{4} \cdot 7 \mathrm{H}_{2} \mathrm{O}, 0.06 \mathrm{~g} \mathrm{MnSO}_{4} \cdot \mathrm{H}_{2} \mathrm{O}$ per $1000 \mathrm{ml}$ aqueous solution. The jars were autoclaved at $121{ }^{\circ} \mathrm{C}$ for $20 \mathrm{~min}$. All specimens were inoculated via an atomizer with $1 \mathrm{ml}$ of the mixed inoculum. All but the WFIB specimens were put on the nutrient-salt-agar, while the WFIB specimens were stamped in the nutrient-salt-agar due to the large thickness. Subsequently, all specimens were covered with $15 \mathrm{ml}$ of nutrient-salt-agar again (Fig. 2). As a reference, malt-agar
(30.0 g malt extract, $3.0 \mathrm{~g}$ soya peptone, $15.0 \mathrm{~g}$ agar-agar, water) was placed in the screw jar replacing the test specimen. All jars were incubated at $22{ }^{\circ} \mathrm{C} \pm 1{ }^{\circ} \mathrm{C}$ and $70 \% \mathrm{RH}$ during 28 days. The deviations in temperature and $\mathrm{RH}$ from the standard were defined through the conditions of the culture room. Other deviations from the standard were made to make it comparable to BS 3900.

Specimens were assessed visually every 2-4 days and images were taken using a digital microscope VHX 5000 (Keyence, Osaka, Japan) at 50x magnification.

\subsection{Evaluation of the mould resistance}

According to both standards, surface colonization by mould is rated visually. In the chamber test according to BS 3900G6 (1989), five mould growth classes are defined, while only three classes are distinguished using the agar plate test method ISO 16869 (2008). To allow for a uniform evaluation of both tests, the following five-class assessment scheme was applied in this experiment:

Class $0=$ no infestation of the surface.

Class $1=1-25 \%$ infestation of the surface.

Class $2=26-50 \%$ infestation of the surface.

Class $3=51-75 \%$ infestation of the surface.

Class $4=76-100 \%$ infestation of the surface.

Deviations from the rating scale of the BS 3900-G6 (1989) were made because it includes very small differences between the classes which are not possible to distinguish by a subjective viability control.

\subsection{Moisture content measurements}

The moisture content (MC) of the specimens was determined after incubation. Therefore, the specimens were cleaned with a soft brush from adhering mould, weighed to the nearest $0.001 \mathrm{~g}$, oven-dried at $103{ }^{\circ} \mathrm{C}$ and after cooling down in a desiccator weighed again.

Equation 1: Moisture content (MC).

$M C=\frac{w-d}{d} * 100$

$\mathrm{MC}=$ moisture content, in $\%$.

$\mathrm{w}=$ wet mass of the test specimen, in grams.

$\mathrm{d}=$ oven dry mass of the test specimen, in grams. 


\section{Results and discussion}

\subsection{Mould resistance of wood-polymer composites (WPC)}

After seven days, the specimens in the agar plate test were already infected; however, in the chamber test, the first infection was observed after 21 days (Fig. 3). Specimens with higher hardwood content showed a higher degree of colonization by the mould fungi in both tests, which might be attributed to the higher amount of hemicellulose in the hardwoods (Findlay and Savory 1954).

At the end of the test, none of the PP and PE specimens were infested neither in the chamber test nor in the agar plate test. Solid beech wood specimens were rated in class 2 in the agar plate test and in class 3 in the chamber test: black locust specimens were rated in class 2 and in class 0 , respectively. The pine sapwood specimens were rated in class 0 (not infected at all) in the agar plate test, but were rated in class 4 in the chamber test. Lie et al. (2019) also found that pine sapwood was nearly not infected in the agar plate test, but this was not the case in an outdoor test. In the relatively small petri dishes, the emissions of volatile organic compounds (VOCs) might act as an antifungal component.
Mould growth on industrially produced WPC started always earlier in the agar plate test compared to the chamber test. Only on three of the WPC produced in laboratory processes (WPC 1-3), the mould growth started at the same time in both tests.

\subsection{Mould resistance of wood fiber insulation boards (WFIB)}

In the agar plate test, the mould growth started always earlier and proceeded faster than in the chamber test. After 28 days, none of the WFIB specimens in the chamber test was infected by mould. Therefore, the test was extended to 60 days. The materials with higher hardwood proportions showed more severe mould growth (Fig. 4).

Unlike Kumar et al. (2016), no positive effect of a hydrophobation additive became visible. Furthermore, there was no effect of the fire retardant additive APP and no significant effect of the binder type (PMDI and bicomponent fibers). The specimens with and without APP and with both types of binder were equally colonized.

Moreover, some of the WFIB specimens were shattered during their placement in the test chamber, because the high porosity of WFIB resulted in brittleness of the specimens.
Fig. 3 Classification of mould growth on WPC specimens during the agar plate test (left) and the chamber test (right)

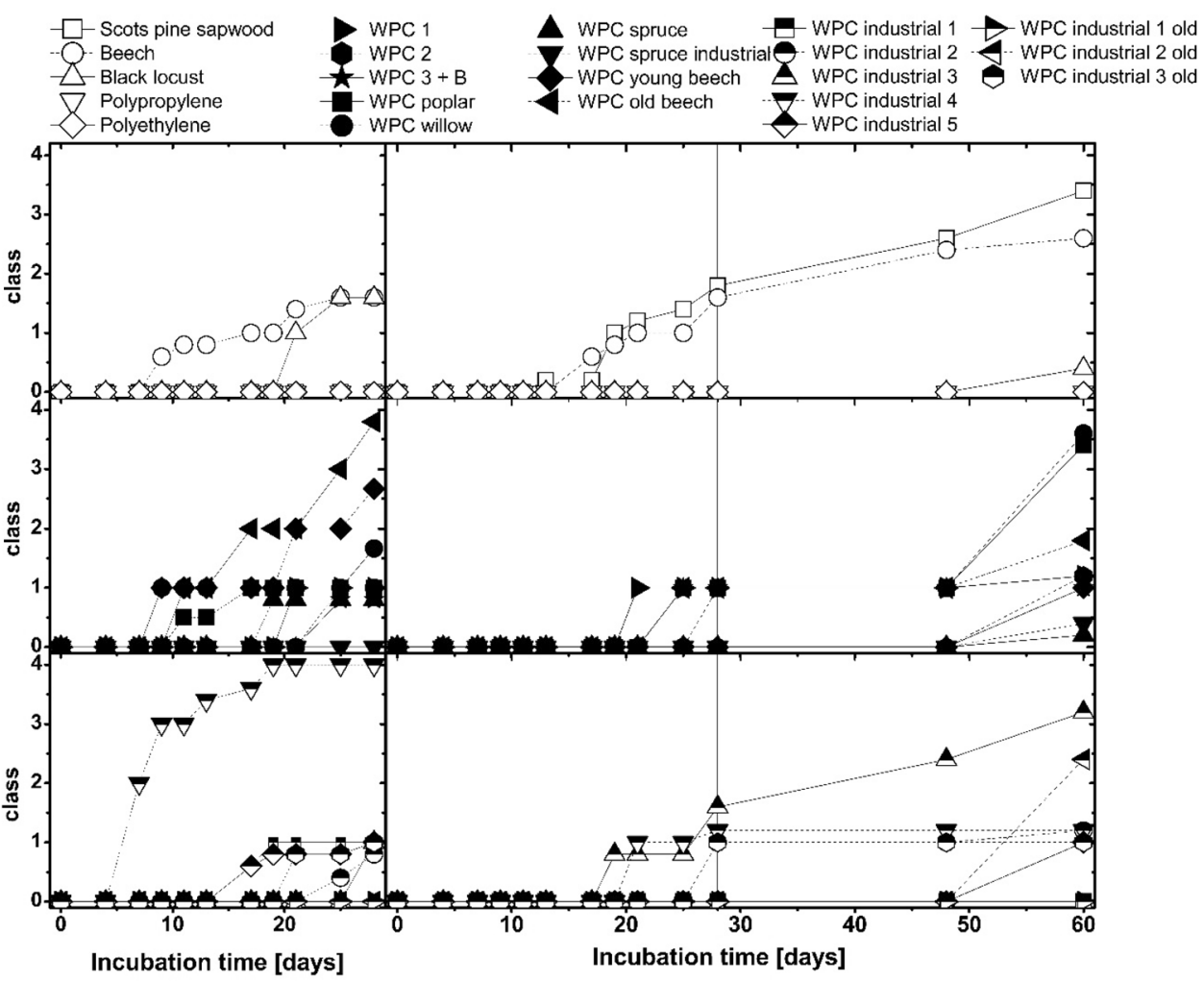


Fig. 4 Mould growth for WFIB during the agar plate test (left side) and the chamber test (right side)

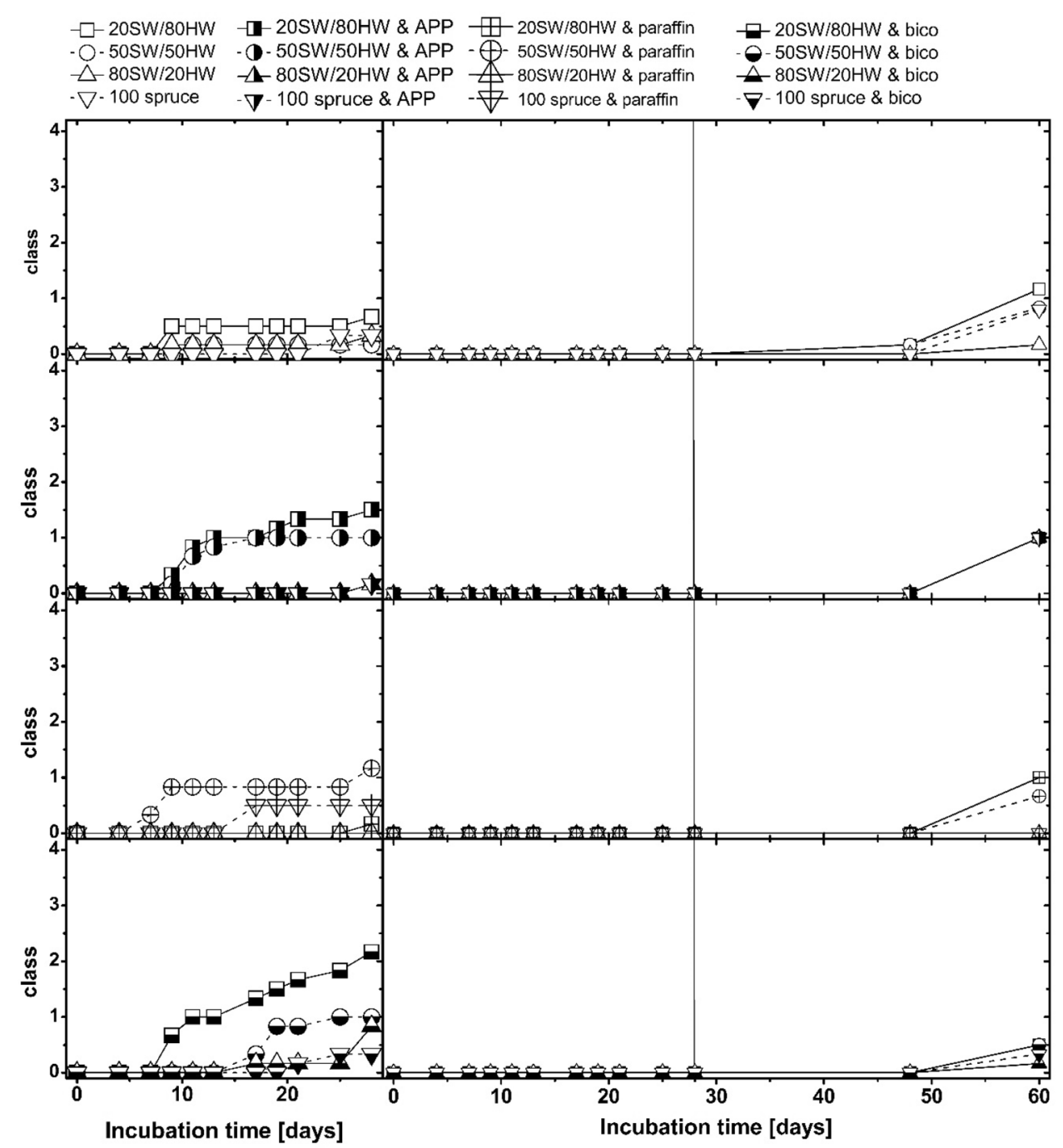

\subsection{Moisture content after incubation}

During the agar plate test, the wood references absorbed clearly the highest amount of water. Scots pine sapwood exhibited an average moisture content of $148.3 \%$, beech of $106.7 \%$ and black locust of ca. $84.2 \%$. In terms of WPC, higher wood content resulted in higher water absorption (Table 3). 'WPC-Industrial 4' (50\% wood percentage) and 'WPC-Industrial 3 old' (75\% wood percentage) absorbed $13.6 \%$ and $23.9 \%$ of water, respectively. This is due to the higher wood particle content of 'WPC-Industrial 3 old'.
The moisture content of all specimens in the chamber test was much lower than that of the specimens in the agar plate test. For the wood references, the values were 15.9\% for Scots pine sapwood, $21.1 \%$ for beech and $13.5 \%$ for black locust. As for the agar plate test, WPCs containing more wood had higher moisture content around 14.6\% (WPC industrial 3 old) compared to the ones containing less wood with $7.9 \%$ moisture content (WPC industrial 4) (Table 3). Clemons (2002) mentioned that the wood flour content, wood particle size, processing methods, and additives influence the moisture absorption of WPC. 
Table 3 Moisture content of the WPC specimens

\begin{tabular}{lll}
\hline Material & \multicolumn{2}{l}{ Mean moisture content (\%) } \\
\cline { 2 - 3 } & Agar plate test & Chamber test \\
\hline Scots pine sapwood & 148.3 & 15.9 \\
Beech & 106.7 & 21.1 \\
Black locust & 84.2 & 13.5 \\
Polypropylene & 0.4 & 0.0 \\
Polyethylene & 0.2 & 0.0 \\
WPC 1 & 21.1 & 11.2 \\
WPC 2 & 19.0 & 14.6 \\
WPC 3 (plus biocide) & 15.4 & 12.6 \\
WPC-Industrial 1 & 21.0 & 13.2 \\
WPC-Industrial 2 & 14.0 & 10.3 \\
WPC-Industrial 3 & 21.5 & 14.9 \\
WPC-Industrial 4 & 13.6 & 7.9 \\
WPC-Industrial 5 & 14.9 & 9.8 \\
WPC-4-poplar & 19.0 & 14.2 \\
WPC-5-willow & 23.0 & 12.8 \\
WPC-6-spruce & 15.7 & 13.6 \\
WPC 7-spruce industrial & 18.8 & 13.4 \\
WPC 8-young beech & 18.3 & 13.2 \\
WPC 9-old beech & 17.0 & 14.1 \\
WPC-industrial 1 (4 years o.e. ${ }^{1}$ ) & 19.9 & 13.4 \\
WPC-industrial 2 (6 years o.e.) & 14.2 & 11.0 \\
WPC-industrial 3 (1 year o.e.) & 23.9 & 14.6 \\
\hline
\end{tabular}

${ }^{1}$ Outdoor exposure

High temperatures (over $10{ }^{\circ} \mathrm{C}$ are required for growth; $30{ }^{\circ} \mathrm{C}$ are favored) and high moisture contents (over 75\%) are favorable for mould growth (Schirp and Wolcott 2005; Krause and Schmid 2012; Ibach et al. 2017). Even though many mould species, which are known to grow on wood, have also been isolated from polymers (Schirp et al. 2008), there was no infection of polyethylene and polypropylene specimens in these tests (Figs. 3 and 5 ). This might be explained by insufficient water uptake of the pure polymers (Caulfield et al. 2005) and a lack of additional nutrients.

As for WPC, the agar plate test led to much higher moisture content of WFIB specimens (up to 908.9\%) compared to the chamber test (up to 212.6\%) (Table 4). This is attributed to the direct contact between the specimens and the agar medium in the agar plate test. In contrast, chamber test specimens took up water only from ambient air in the chamber based on diffusion and condensation only.

\subsection{Comparison of methods}

As most of the chamber test specimens were not infected even after 28 days of incubation, ratings were done after 60 days. However, mould growth ratings did not correlate between the two test methods, neither after 28 days nor after 60 days, and neither for WPC nor for WFIB (Fig. 6). The mould fungi grew much faster in the agar plate test than in the chamber test due to the presence of malt extract agar and higher moisture content (Bardage 2004; Schirp et al. 2008).

There are many implications that can affect mould growth; for instance, the surface structure of the specimens. Gobakken et al. (2010) tested mould growth on paints with different surface structures. They examined six different model paints and found that the mould growth varied with exposure time and type of paint. They suggested that differences in surface structure affect spore attachment and germination, but this did not become evident from their results. They explained that the chemical effect in the coating could be as important as, or more important than, the physical characteristic of the surface.

Moreover, in this study, chemical and/or physical characteristics of the surface could have had an influence on the mould growth, because there were very different surface structures (2.1.1 and 2.1.2) and the chemical ingredients changed a lot between the different variations. The two different additives (APP and paraffin) and binders (PMDI and bicomponent fibers) used for WFIB production influence chemical surface properties.



Fig. 5 Mould growth classes from 0 (left) to 4 (right) 
Table 4 Moisture content of the WFIB specimen

\begin{tabular}{lllc}
\hline Material & Additives & $\begin{array}{l}\text { Mean moisture content } \\
(\%) \\
\text { Agar plate test }\end{array}$ & $\begin{array}{l}\text { Mean moisture } \\
\text { content } \\
\text { Chamber test }\end{array}$ \\
\hline 20SW/80HW & PMDI (5\%) & 242.3 & 100.8 \\
50SW/50HW & PMDI (5\%) & 161.0 & 86.5 \\
80SW /20HW & PMDI (5\%) & 140.7 & 86.2 \\
100 Spruce & PMDI (5\%) & 438.1 & 132.0 \\
20SW/80HW & PMDI (5\%) \& APP (10\%) & 840.3 & 212.6 \\
50SW/50HW & PMDI (5\%) \& APP (10\%) & 881.5 & 205.9 \\
80SW/20HW & PMDI (5\%) \& APP (10\%) & 765.8 & 161.7 \\
100 Spruce & PMDI (5\%) \& APP (10\%) & 532.9 & 189.6 \\
20SW/80HW & Bico (7\%) & 722.8 & 11.2 \\
50SW/50HW & Bico (7\%) & 908.9 & 133.3 \\
80SW/20HW & Bico (7\%) & 436.9 & 88.4 \\
100 Spruce & Bico (7\%) & 446.5 & 108.5 \\
20SW/80HW & PMDI (5\%) \& paraffin (1\%) & 130.6 & 137.5 \\
50SW/50HW & PMDI (5\%) \& paraffin (1\%) & 151.4 & 178.7 \\
80SW/20HW & PMDI (5\%) \& paraffin (1\%) & 112.5 & 138.6 \\
100 Spruce & PMDI (5\%) \& paraffin (1\%) & 439.9 & \\
\hline
\end{tabular}

In addition, the duration of a mould growth experiment plays an important role, since the risk of mould infestation increases with incubation time (Johansson et al. 2012). Hence, future studies shall include long-term outdoor experiments with matched samples to allow for a direct comparison with results from laboratory tests as presented in this study.

Apart from this, different mould growth classification systems are used according to the two standards. In some publications, 'classes' are also referred to as 'index'. Further, Ojanen et al. (2010) report that the defined intervals for the classification vary in different studies. These different assessment systems lead to very poor comparability of the different standards.

\subsection{Microscopic evaluation of the mould fungi growth}

The microscopic evaluation of the mould growth at $50 \mathrm{x}$ magnification turned out unfeasible, because the specimens' surfaces were very heterogeneous, and thus prone to create shadows and irregularities, which made it impossible to evaluate the infected surfaces.

\section{Conclusion}

Mould growth ratings obtained with the chamber method and the agar plate method were not well correlated, neither within the group of materials nor across different materials. This was attributed to the much higher moisture content and additional nutrients available for the specimens in the agar plate test compared to those in the chamber test. Thus, for the interpretation of the results, it is very important to know and clearly indicate which standard was used.

Some of the WFIB specimens disintegrated during installation in the test chamber because they were too brittle. For future experiments, it is therefore recommended to use a wire basket or a similar support, when handling WFIB specimens.

Finally, the chamber test appeared preferable over the agar plate method because it represents more realistic exposure conditions for wood-based materials compared to the agar plate test. One more reason that makes 


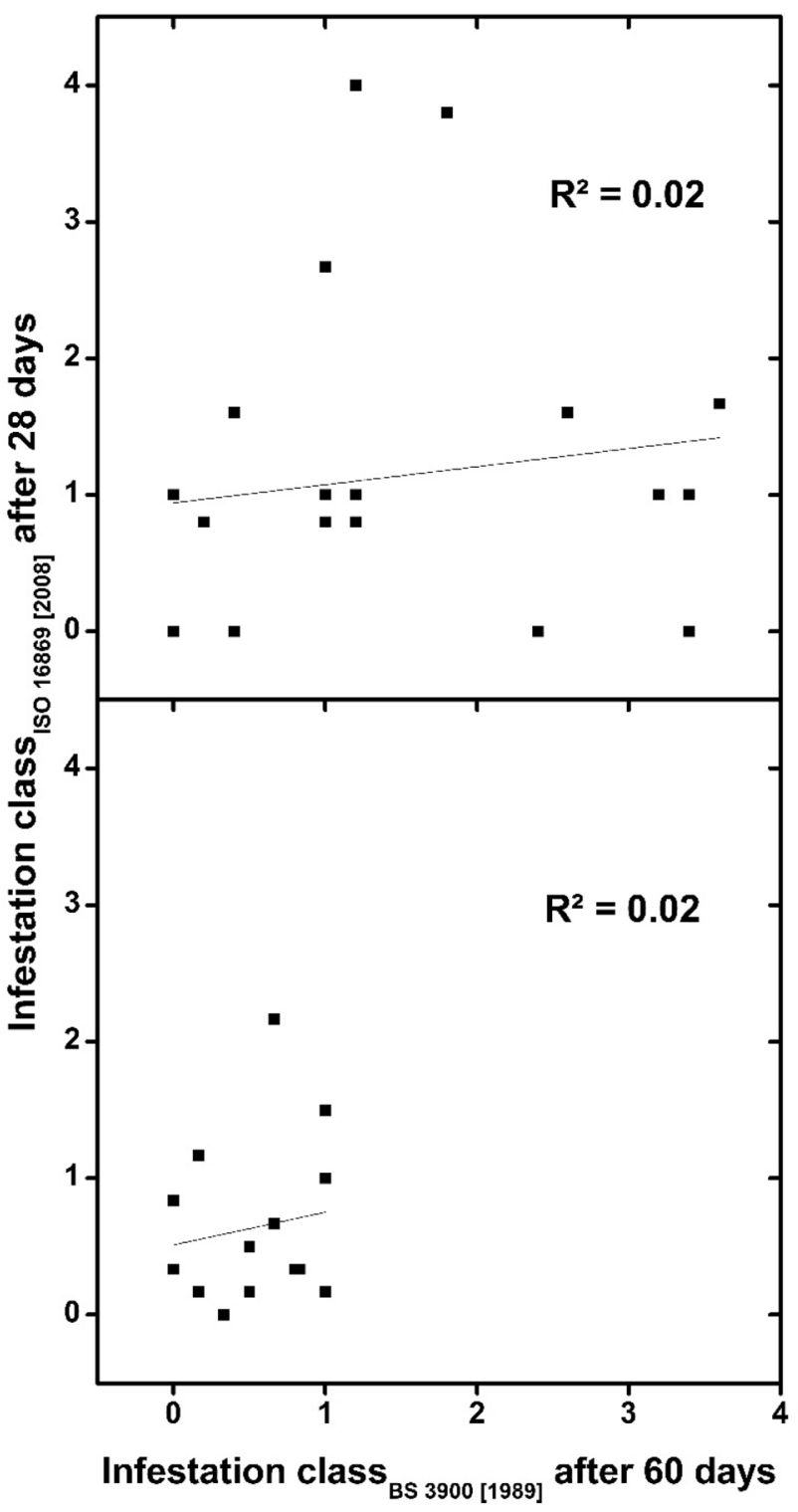

Fig. 6 Correlation between mould infestation classes according to ISO 16869 (2008) and BS 3900 (1989) for the WPC (above) and WFIB (below) specimens at the end of the tests. Each point represents the arithmetic mean of one material

the chamber test more comparable to materials used in construction than the agar plate test is that there are no artificially added nutrients. For further validation of the method, field test experiments under different exposure regimes are in preparation.

Acknowledgements Open Access funding provided by Projekt DEAL. The authors are grateful for financial support in the frame of the projects "WPC-BIO-DEG" (18950N/2) by AIF-IGF (Arbeitsgemeinschaft industrieller Forschungsvereinigungen „Otto von Guericke“
e.V.-Industrielle Gemeinschaftsforschung) and "GerLau" (22015615) by Fachagentur für Nachwachsende Rohstoffe e.V. (FNR).

\section{Compliance with ethical standards}

Conflict of Interest The authors declare no conflicts of interest.

Open Access This article is licensed under a Creative Commons Attribution 4.0 International License, which permits use, sharing, adaptation, distribution and reproduction in any medium or format, as long as you give appropriate credit to the original author(s) and the source, provide a link to the Creative Commons licence, and indicate if changes were made. The images or other third party material in this article are included in the article's Creative Commons licence, unless indicated otherwise in a credit line to the material. If material is not included in the article's Creative Commons licence and your intended use is not permitted by statutory regulation or exceeds the permitted use, you will need to obtain permission directly from the copyright holder. To view a copy of this licence, visit http://creativecommons.org/licenses/by/4.0/.

\section{References}

ASTM D 3273-00 (2000) Standard Test Method for Resistance to Growth of Mold on the Surface of Interior Coatings in an Environmental Chamber, ASTM International, West Conshohocken, PA

Bardage SL (2004) Assessment of mould growth, COST E18-Symposium on Measurement Methods, 16-17 February, Copenhagen

BS 3900 Part G6 (1989) British Standard Methods of test for paints Part G6. Assessment resistance to fungal growth. British Standards Institution (BSI), London

Caulfield DF, Clemons C, Jacobson RE, Rowell RM (2005) Wood thermoplastic composites. In: Handbook of wood chemistry and wood composites. CRC Press, Boca Raton, pp 365-378

Clemons CM (2002) Wood-Plastic Composites in the United States The Interfacing of Two Industries. Forest Products Journal, 52: $10-18$

EN 60068-2-10 (2006) Environmental testing - Part 2-10: Tests - Test J and guidance: Mould growth (IEC 60068-2-10:2005), European Committee for Standardization (CEN), Brussels

EN 15101-1 (2013) Thermal insulation products for buildings - In-situ formed loose fill cellulose (LFCI) products - Part 1: Specification for the products before Installation European Committee for Standardization (CEN), Brussels

EN 15457 (2014) Paints and varnishes-laboratory method for testing the efficacy of film preservatives in a coating against fungi. European Committee for Standardization (CEN), Brussels

EN 15534-1 (2018) Composites made from cellulose-based materials and thermoplastics (usually called wood-polymer composites (WPC) or natural fibre composites (NFC)) - Part 1: Test methods for characterization of compounds and products. European Committee for Standardization (CEN), Brussels

Findlay WPK, Savory JG (1954) Moderfäule. Die Zersetzung von Holz durch niedere Pilze. [Soft rot. The decomposition of wood by lower fungi.] Holz Roh- Werkst 12: 293-296

Gobakken LR, Høibø OA, Solheim H (2010) Mould growth on paints with different surface structures when applied on wooden claddings exposed outdoors. International Biodeterior Biodegr 64 (2010), 339-345

Holzmann G, Wangelin M, Bruns R (2012) Natürliche und pflanzliche Baustoffe. Rohstoff - Bauphysik - Konstruktion. [Natural and vegetable building materials. Raw material - building physics - construction.] Vieweg+Teubner, Wiesbaden 
Hundhausen U, Reimann C, Gobakken LR (2013) Evaluation of mould growth on coated wood using digital image analysis (ImageJ). In: COST Action FP1006 "Bringing new functions to wood through surface modification" 3rd Workshop - "Process and Service life modelling". Ghent, Belgium

Ibach RE (2010) Durability of wood-plastic composite lumber. In: Mc-Graw-Hill yearbook of science and technology 2010. McGraw-HillNew York, NY, pp 113-116

Ibach RE, Gnatowski M, Sun G (2013) Field and laboratory decay evaluations of wood-plastic composites. For Product J 63:76-87

Ibach RE, Gnatowski M, Sun G, Glaeser J, Leung M, Haight J (2017) Laboratory and environmental decay of wood-plastic composite boards: flexural properties. Wood Mat Sci Eng 13(2):81-96

ISO 16869 (2008) Plastics-Assessment of the effectiveness of fungistatic compounds in plastics formulations. International Organization for Standardization, Switzerland

ISO 16000-21 (2014) Indoor air - Part 21: detection and enumeration of moulds-Sampling from materials. International Organization for Standardization, Switzerland

ISO 846 (2018) Plastics-Evaluation of the action of microorganisms (ISO/DIS 846:2018). International Organization for Standardization, Switzerland

Johansson P, Ekstrand-Tobin A, Svensson T, Bok G (2012) Laboratory study to determine the critical moisture level for mould growth on building materials. Int Biodeterioration Biodegr 73:23-32

Karus M, Ortmann S, Schmidt C, Gahle C (2006) Märkte in Nordamerika, Japan und Europa mit Schwerpunkt auf Deutschland. Technische Eigenschaften-Anwendungsgebiete PreiseMärkte-Akteure. [Markets in North America, Japan and Europe with a focus on Germany. Technical characteristics - fields of application prices - markets - actors] Nova Institut für Ökologie und Inovation. http://nova-institut.de/pdf/0601_WPC-Studie.pdf. Accessed 10 Oct 2019

Krause A, Schmid M (2012) WPC-Allgemeine Charakteristik und Lebensdauer im Vergleich zu Holz. [WPC-General characteristics and service life compared with wood] Deutsche Holzschutztagung. Trends und Chancen. Göttingen, 27-28 September 2012. pp 149-161

Krug D (2010) Einfluss der Faserstoff-Aufschlussbedingungen und des Bindemittels auf die Eigenschaften von mitteldichten Faserplatten (MDF) für eine Verwendung im Feucht- und
Außenbe-reich. [Influence of the pulping conditions and the binder on the properties of medium density fibreboard (MDF) for use in moist and outdoor areas], Dissertation. Universität Hamburg

Kumar A, Stanek K, Ryparova P, Hajek P, Tywoniak J (2016) Hydrophobic treatment of wood fibrous thermal insulator by octadecyltrichlorosilane and its influence on hygric properties and resistance against moulds. Compos B Eng 106:285-293

Lie SK, Vestøl GI, Høibø O, Gobakken LR (2019) Surface mould growth on wood: a comparison of laboratory screening tests and outdoor performance. Eur J Wood Prod 77:1137-1150

Ojanen T, Lähdesmäki K, Viitanen H, Vinha J, Peuhkuri R, Salminen K (2010) Mold growth modeling of building structures using sensitivity classes of materials. ASHRAE Buildings XI Conference, Dec. 5-9, 2010 Clearwater Beach, Florida. 2010. p. 1-10

Plaschkies K, Scheiding W (2014), Susceptibility of wood-polymer composites against mould, wood staining fungi and algae. International Conference Kranjska Gora, Slovenia, pp 15-16

Robbins C, Morrell J (2002) Mold, Housing and Wood. Western Wood Products Association, Portland

Scheiding W (2007) Schimmelpilzbefall an Holz und Holzwerkstoffen. [Mould infestation of wood and wood composites] 25. DGfH-Holzschutz-Tagung, 20-21. September 2007, Biberach/ Riß, Germany

Schirp A, Wolcott MP (2005) Influence of fungal decay and moisture absorption on mechanical properties of extruded wood-plastic composites. Wood Fiber Sci 37(4):643-652

Schirp A, Ibach RE, Pendleton DE, Wolcott MP (2008) Biological degradation of wood-plastic composites (WPC) and strategies for improving the resistance of WPC against biological decay. ACS Symposium Series, 982: 480-507

Schmidt O (1994) Holz- und Baumpilze: Biologie, Schäden, Schutz, Nutzen. [Wood and tree fungi: Biology, decay, protection, use.]. Springer, Berlin

Sutter H-P (2002) Holzschädlinge an Kulturgütern erkennen und bekämpfen. [Recognize and combat wood pests on cultural goods]. Paul Haupt, Bern

Publisher's Note Springer Nature remains neutral with regard to jurisdictional claims in published maps and institutional affiliations. 